\title{
An Empirical Analysis of the Impact of Fiscal and Tax Incentives on Enterprise Technological Innovation - Taking Listed Companies on GEM as Examples
}

\author{
Junda Yang ${ }^{1}$, Yun Xia ${ }^{1}$, Liu Yang ${ }^{1} \&$ Zhongtao Zhang ${ }^{1}$ \\ ${ }^{1}$ Finance Department of International Business School, Jinan University, Zhuhai, China \\ Correspondence: Yun Xia, Finance Department of International Business School, Jinan University, Qianshan \\ Road 206\#, Zhuhai City, Guangdong Province, Post No.519070, China. E-mail: 13676097885@163.com
}

Received: October 22, 2018

Accepted: November 19, $2018 \quad$ Online Published: November 21, 2018

doi:10.5539/ibr.v11n12p42

URL: https://doi.org/10.5539/ibr.v11n12p42

\begin{abstract}
Enterprise technological innovation is the backbone of the transformation of economic development mode in China, the optimization of economic structure, and the realization of national innovative development strategy. In order to promote the transformation and upgrading of the economic structure and encourage the the development of technological innovation of enterprises, a series of fiscal and tax policies which encourage technological innovation are introduced in China. Although the fiscal and tax incentives are generally adopted by the governments of the world, the research conclusions of the academia on the implementation effect of fiscal and tax policies are not unified. For this reason, in this paper, based on the data of listed companies on the Growth Enterprise Market from 2011 to 2017, the STATA 14.0-version software is used to analyze the sample data, and the relationship between the current fiscal policies and technological innovation is explored. The study results show that the fiscal and tax incentives positively affect the technological innovation of enterprises, which provides an important theoretical basis for the government to further improve fiscal and tax policies. Finally, based on the previous research contents, the corresponding conclusions are summarized, and relevant suggestions for improving the fiscal and tax incentive policies are proposed.
\end{abstract}

Keywords: fiscal and tax incentives, technological innovation, growth enterprise market

\section{Introduction}

Enterprise technological innovation is the backbone of the transformation of economic development mode in China, the optimization of economic structure, and the realization of national innovative development strategy. Especially, the transformation of technology into production achievements by enterprises will directly affects the economic benefits and social and economic development of enterprises. According to relevant surveys, the contribution rate of current technological innovation in China to the economic growth remains at around 75\% in recent years, dropping 18 percentage points compared with $93 \%$ in 2009 (Guirong Zhou et al., 2018). This shows that the cost of technological innovation of enterprises in China is relatively improved, and that the efficiency of transforming technology into direct production achievements is not significant. In order to improve the bottleneck of enterprise technological innovation, a series of policy guidelines are introduced in China. Since the introduction of the "strategy of invigorating China through science and education" in 1998 and the "innovation-driven development strategy" at the 19th National Congress, China has been committed to promoting the innovation and development of science and technology. While the fiscal and tax incentives greatly affect the technological innovation. In 2017, the annual R\&D expenditure in 2017 reached 1.75 trillion yuan, with an increase of $11.6 \%$ compared with the previous year, and the pace of technological innovation of enterprises has also accelerated.

In order to promote the transformation and upgrading of the economic structure and encourage the development of technological innovation of enterprises, a series of fiscal and tax policies that encourage the technological innovation has been introduced in China. All of these have promoted the commercial transformation of the technological innovation achievements in enterprises and played an important role in the improvement of innovation performance in enterprises. Although the fiscal and tax incentives are generally adopted by the governments of the world, the research conclusions of the academia on the implementation effect of fiscal and 
tax policies are not unified. Then, what is the role of fiscal and tax incentives, and can it promote enterprises to carry out technological innovation activities and improve the innovation performance? These problems need to be further settled by theoretical analysis and empirical analysis. In view of this, in this paper, based on the data of listed companies on the Growth Enterprise Market from 2007 to 2017, the STATA 14.0-version software is used to analyze the sample data, and the relationship between the current fiscal policies and technological innovation is explored. The study results show that the fiscal and tax incentives positively affect the technological innovation of enterprises, which provides an important theoretical basis for the government to further improve fiscal and tax policies.

\section{Literature Review}

\subsection{Research Status of the Impact of Fiscal Subsidy Incentive Policies on Technological Innovations in Enterprises}

Domestic and foreign scholars have studied whether fiscal subsidies affect the technological innovation in enterprises. Some scholars hold that the fiscal subsidy incentive policies can effectively promote the technological innovation in enterprises, while other scholars hold dissenting opinions. After reading a large amount of literature in the study, we summarize the relevant points in this section.

(1) The fiscal subsidy incentive policies have a positive effect on the technological innovation in enterprises.

Fiscal subsidy incentive policies can promote the technological innovation. Holger Gorg and Eric Strobl (2007) held that there were fiscal subsidy incentive differences in different types of enterprises, and that after receiving fiscal subsidies for enterprises, medium and small-sized enterprises would apply the subsidies to the R \& D investment. Therefore, the fiscal subsidy incentive policies have positive significance for the technological innovation in small and medium-sized enterprises. Lv Jiuqin and Yu Dandan (2011) conducted research based on the sample data from 2007 to 2008 of listed companies. And the empirical studies showed that after receiving the fiscal subsidies form government, the listed companies would apply the subsidies to the R\&D expenditure in the next year. In other words, the government fiscal subsidy incentive policies have a positive effect on the technological innovation in enterprises. Ajay Aggarwal and Richard Sullivan (2014) conducted a research based on 300 sample data and found that the government fiscal subsidies had an inverted " $U$ " relationship to the technological innovation of enterprises. This means that there is a limit to the government fiscal subsidies to the technological innovation. Within a certain reasonable range, the fiscal subsidies have positive significance for the technological innovation of enterprises. They conducted conclusions from the empirical research that the government should rationally invest in the technological innovation of enterprises. Ren Shuwei and Ju Xiaofeng (2016) explored the relationship between fiscal policies and technological innovation of small and medium-sized enterprises based on the ESN model. With the fiscal policies as the characterization variables, the fiscal policies significantly and positively correlate to the technological innovation of enterprises. This shows that the fiscal policies have strengthened the investment of technological innovation in small and medium-sized enterprises. Li Zhaoyou and Qi Xiaodong (2017) took the data of 65 listed companies in the new energy automotive industry in China as the the research sample, and found through the construction of empirical models that the impact of government subsidies on the R\&D investment and patent output of enterprises was distributed in a "inverted U" shape. In general, the fiscal subsidy incentives in China have a positive effect on the technological innovation in enterprises.

(2) Fiscal subsidy incentive policies have a negative effect on the technological innovation in enterprises.

Some domestic and overseas scholars held that the direct subsidies to the R \& D activities of enterprises will restrict the enthusiasm of enterprises to invest in innovation to a certain extent. Tommy (2009) believed that fiscal subsidies had a substitution effect on the R\&D investment of enterprises and could reduce the innovation performance. Yu Minggui, Hui Yafu and Pan Hongbo (2010) believed that private enterprises that established political connections with local governments could get more financial subsidies, and that these private enterprises did not apply subsidies to the R\&D activities, but to expand the size of enterprises. Gao Hongwei (2011) constructed the theoretical models based on the game theory and explored the impact of government subsidies on the technological innovation in state-owned enterprises. And it was found through empirical studies that the increase in government subsidies would lead to the crowding out effect of research and development in state-owned enterprises, and that the state-owned enterprises would use special political connections to defraud fiscal subsidies and may even lead to widespread corruption. Cao Xianfei (2014) explored the relationship between fiscal subsidies and technological innovation of enterprises based on propensity score matching difference method. And through empirical research he found that there was an inverted " $U$ " relationship between the promotion effect of government fiscal subsidies and the intensity of subsidies, and that in the actual 
technological innovation in enterprises, excessive fiscal subsidies often led to the deviation of the direction of subsidies. Camila Gramkow and Annela Anger-Kraavi (2018) held that the fiscal subsidies had a reverse effect on the technological innovation in enterprises. In the research, they found that companies that received fiscal subsidies would cut the investment of equity capital in technology input. The more government fiscal subsidies will replace the R \& D input of the equity capital of enterprises. In other words, the government fiscal subsidies can not achieve the desired results. Guo Jingxian and Yuan Zeming (2018) held that the fiscal subsidies have some crowding out effect on the technological innovation in enterprises. The purpose of the government fiscal subsidies for enterprises is to promote enterprises to use subsidies to invest in the technology research and development. While, in the process of investing in real technology research and development, companies often use fiscal subsidies in other directions, leading to a waste of fiscal resources in technological innovation.

\subsection{Research Status of the Impact of Preferential Tax Incentive Policies on the Technology Innovation in Enterprises}

The academic circles at home and abroad believed that preferential tax incentive policies play an important role in the technological innovation in enterprises. The content of this section will be elaborated on the impact of preferential tax incentive policies on the R\&D innovation investment of enterprises and the impact of preferential tax policies on the $R \& D$ innovation output of enterprises.

\section{(1) Impact of preferential tax policies on the technology innovation in enterprises}

Preferential tax policies can stimulate innovation activities and promote technological innovation. Dominique (2003) conducted empirical researches based on data of corporate R\&D innovation investment of 17 OECD countries. The empirical researches showed that the preferential tax policies can alleviate the cost of corporate R\&D innovation, and thus mobilizing the enthusiasm of technological innovation in enterprises. Xu Jingting, Zhang Bing and Yan Shenyou (2013) took the preferential tax policies of Jiangsu Province as an example by the method of qualitative analysis, and revealed the relationship between preferential tax policies and technological innovation in enterprises. They found from researches that preferential tax policies played a leveraging role in the technological innovation in enterprises, which strongly supported the development of technological innovation in enterprises. Based on a survey of the technology innovation data of American enterprises, Shahrouz Abolhosseini and Almas Heshmati (2014) found that the technological innovation capability of enterprises increased by 0.8932 percentage points for every 1 percentage point of increase of tax preferences. It can be seen that the preferential tax policies have a significant positive effect on technological innovation of enterprises. Yuan Jianguo, Fan Wenlin and Cheng Chen (2015) explored the relationship between preferential tax policies and technological innovation in enterprises with the data of China's A-share listed companies from 2006 to 2013 as the research sample. Through empirical researches, it was found that the preferential tax policies had an important role in promoting the R\&D investment of enterprises. At the same time, they further confirmed the difference in the incentive effect of preferential tax policies in different regions and of different types of enterprises on the technological innovation of enterprises. Huang Haibin, Luo Jun and Chang Jing (2017) found that the incentive effect of preferential tax policies on the technology research investment in enterprises is conditional based on the analysis of preferential tax policies for high-tech industries. The basic precondition is that enterprises have interests. In other words, the greater the taxable income is, the greater the incentive effect is. However, some scholars are skeptical about the view that "preferential tax policies promote the technological innovation in enterprises". Wu Jinming (2016) and Yang Xudong (2018) held that the preferential tax policies had a reverse effect on the technological innovation in enterprises.

(2) Impact of preferential tax policies on the $R \& D$ innovation output of enterprises

Czarnitzki D and Hanel P \& Rosa J (2011) found that the reduction in tax burden had a positive impact on the innovation output indicators, based on the empirical analysis of sample data. In other words, preferential tax policies can effectively promote the increase of technological innovation output in enterprises. Li Linmu and Guo Cunzhi (2014) conducted researches based on high-tech industries and found that preferential tax policies positively affected the technological innovation output of enterprises, and that the tax reduction or exemption policies could enable enterprises to have more new products or new patents. Zheng Chunmei and Li Pei (2015) held that preferential tax policies would produce opposite incentive effect under different types of enterprises. Preferential tax policies enjoyed by large companies can stimulate the technological innovation output in enterprises. The preferential tax policies for small and medium-sized enterprises has little effect on the technological innovation output in enterprises. Zhou Xiaodan (2016) conducted empirical researches based on the sample data of A-share listed companies, and found that nominal preferential tax policies and actual preferential tax policies significantly and positively affected the R\&D and innovation output of enterprises. Gao 
Kaidi (2018) conducted empirical researches based on the panel data of 520 listed companies in 2016. And the empirical researches showed that tax preferences had a positive incentive effect on the R\&D and innovation output of enterprises, and that as an intermediate variable between tax preferences and enterprise innovation, $R \& D$ investment played a conductive role in the process of impact. In view of this, academic circles at home and abroad generally believe that preferential tax policies can promote the technological innovation output of enterprises, However, since there are some deficiencies for tax policies in the implementation, the quality of technological innovation output of enterprises is not high.

\subsection{Literature Summary}

Through the writing of the literature review, the following conclusions are summarized. Firstly, the academic circles at home and abroad focus on the researches of impact of fiscal and tax incentive policies on the technological innovation in enterprises, and emphasize the role of fiscal subsidies in the technological innovation in enterprises. Secondly, the academic circles at home and abroad adopt empirical research method to explore the impact of fiscal and tax incentive policies on the technological innovation in enterprises. But different scholars may draw different conclusions based on different variables. Finally, the research on the synergistic effect between fiscal subsidies and tax preferences in the academic circles at home and abroad is still insufficient. In view of this, in this paper, the impact of fiscal subsidies and tax preferences on the technological innovation in enterprises is explored, and the impact of synergistic effect between fiscal subsidies and tax preferences on on the technological innovation in enterprises is studied.

\section{Empirical Analysis of the Impact of Fiscal and Tax Incentives on the Technology Innovation in Enterprises}

The analysis is conducted in this chapter based on the sample data of 243 listed companies on GEM from 2010 to 2017. The impact of fiscal and tax incentives on the technological innovation in enterprises is explored in this chapter by defining relevant variables and constructing theoretical models. And the impact of fiscal and tax incentives on the technology innovation in enterprises, the impact of different fiscal and tax incentives on the technology innovation in enterprises, and synergistic effect between tax preferences and government subsidies are explored based on the theoretical models.

\subsection{Research Design}

\subsubsection{Research Hypothesis}

Based on the theoretical basis of the foregoing chapters and the description of the basic situation, the following three aspects of hypotheses are proposed in this section, In order to better construct the theoretical models and explore the impact of fiscal and tax incentives on the technological innovation in enterprises, the three proposed hypotheses are as follows.

Tax preferences and government subsidies, as two manifestations of fiscal and tax incentive policies, have different effects on the technological innovation. Government subsidies could reduce the cost of technological innovation in enterprises through the support of special capital, thus effectively improving the enthusiasm of technological innovation in enterprises (Fan Zhang, Youdou Zhang, 2018). The goal of tax preferences is the high-tech enterprises, not technological innovation activities. Therefore, there are differences between the effect of tax preferences on technological innovation in enterprises and fiscal subsidies. In view of this, the hypothesis 1 in the research is proposed in this paper: tax preferences and government subsidies affect the enterprises' $R \& D$ investment and the enterprises' innovation ability.

Tax preferences and government subsidies are two different forms of fiscal and tax incentive policies, and there are must differences between their effects on technological innovation in enterprises. The essence of the two incentives, tax preferences and government subsidies, is whether there is support of special funds. Fiscal subsidy is an incentive for the government to use public account funds to support enterprises for technological innovation. While tax incentive is an incentive to stimulate enterprises for technological innovation through tax cuts and tax exemptions for projects related to the technological innovation in enterprises. The academic circle believed that government subsidies could promote the technological innovation in enterprises (Chen Dai, Yi Liu, 2008). In view of this, hypothesis 2 is proposed in this paper: compared with tax preferences, government subsidies can promote the $\mathrm{R} \& \mathrm{D}$ investment in enterprises, that is, government subsidies can play a more incentive role than tax preferences and enhance enterprises' innovation capability.

Tax preferences and government subsidies are effective incentives for technological innovation in enterprises. From this perspective, tax preferences and government subsidies make important contributions to the advancement of technological innovation in enterprises. And scholars in academic circle held that there is a 
synergistic effect between tax preferences and government subsidies. Based on the synergistic effect of tax preferences and government subsidies, whether fiscal incentive had a significant impact on technological innovation in enterprises was determined (Haoyan $\mathrm{Li}$, Jinghua Cui, 2014). In view of this, hypothesis 3 is proposed in this paper: tax preferences have synergistic effects with government subsidies.

\subsubsection{Variable Selection}

The types of variables involved in this paper include explanatory variables, interpreted variables, and control variables.

(1) Explanatory variables

Enterprises' R\&D Investment (RD). According to the main content of this paper, the enterprises' R\&D investment belongs to the explanatory variables. In order to further quantify the status of enterprises' technology innovation, enterprises' R\&D investment adopted by Ying Chen (2016) is drew on in this paper to measure the technological innovation in enterprises.

In the research of this paper, the $R \& D$ investment of enterprises is measured by the ratio of $R \& D$ expenditure to operating income.

Technological Innovation Efficiency of Enterprises (INNOV). In addition to taking the enterprises' R\&D investment as an indicator to measure the technology innovation in enterprises, we also incorporate the technology innovation efficiency of enterprises into the scope of enterprise technology innovation index. The efficiency of enterprise technology innovation measures the "quality" of enterprise technology innovation. In this paper, the ratio of the number of patent applications in the current year to the R\&D investment in the previous year is used to measure the innovation efficiency of enterprises (Qian Xin et al.,2018). As this measurement index belongs to the stock index of enterprises, and the key variable fiscal subsidy and income tax preference are flow indexes of the government, this method is adopted.

(2) Interpreted variables

Financial Subsidy Intensity (FS). The intensity of financial subsidies is an important indicator of financial subsidies for the technological innovation in enterprises. Therefore, in this paper, the intensity of financial subsidies is taken as an important criterion for measuring the fiscal and tax incentive policies. According to the calculation method commonly used in academia, the ratio of government fiscal subsidies obtained by enterprises to the operating income is taken as the calculation standard.

Income Tax Benefit (ITB). Income tax benefit is an important criterion for tax preferences to stimulate technological innovation in enterprises. Therefore, in this paper, the income tax benefit is taken as another standard to measure the fiscal and tax incentive policies. According to the calculation method of academia, the ratio of corporate income tax to the operating income is used as the calculation method.

(3) Control variables

The factors affecting enterprises' technological innovation also include important economic indicators, such as total return on assets, return on equity, asset-liability ratio and nature of property rights. In order to more scientifically explore the impact of fiscal and tax incentive policies on enterprises' technology innovation policies, the relevant factors of enterprises' technology innovation are incorporated into the scope of control variables in this paper.

Total Return on Assets (ROA). The total return on assets has an important impact on the technological innovation of enterprises. The higher the total return on assets is, the stronger the profitability of enterprises is, and the stronger the investment in technological innovation is. the ratio of net profit to average total assets is used to measure the total return on assets in this paper.

Return on Equity (ROE). The return on equity has an important impact on the technological innovation in enterprises. The higher the return on equity is, the stronger the profitability of enterprises is, and enterprises will have huge economic strength to invest in technological innovation. The ratio of total net profit of enterprises to owner's equity is used to measure the return on equity of enterprises in this paper.

Sales Margin (SM). The ratio of the main business profit to the main business cost is used to measure the net sales gross margin in this paper.

Asset-Liability Ratio (ALR). The asset-liability ratio reflects the solvency of enterprises, that is, the stronger the solvency of enterprises, the more capital it can invest in technological innovation. The ratio of total liabilities to total assets is used to measure the asset-liability ratio in this paper. 
Capital adequacy (lcash). The logarithm of cash holdings is used to measure the capital adequacy in this paper. The higher the capital adequacy, the more the disposable capital of enterprises is, and the more the funds can be used for technological innovation is.

Enterprise size (SIZE). The enterprises' total assets at the end of the year are used to measure the enterprise in this paper. The enterprise size will affect the technological innovation in enterprises. In order to eliminate heteroscedasticity, this indicator uses the logarithm of total assets at the end of the year to measure the enterprise size.

Government Quality (GQ). Government quality represents the quality of the government in the region where the enterprise is located. The relevant indicators in the "China Provincial Marketization Index Report (2016)" compiled by Wang Xiaolu, Fan Gang, and Yu Jingwen is used in this paper to measure the institutional environment. The smaller the index is, the lower the rule of law is and the worse the institutional environment is. When the index in this region where the enterprise is located is lower than the median of the sample region, the GQ dummy variable is defined as 0 , whereas the variable is defined as 1 .

Political connection of corporate executives (Political). This variable is also a dummy variable. When a board member of an enterprise has served in the party and government departments, or obtained titles at various levels, such as "NPC Deputy" and "CPPCC Member", he Political dummy variable is defined as 1, whereas the variable is defined as 0 . This data is derived from the background information of the board of directors and management information disclosed in the annual report of the listed companies, and is obtained through manual finishing.

Property Right of Enterprise (SOE). If the enterprise is a state-owned enterprise, it takes 1; otherwise, it takes 0. Ownership concentration of enterprise (the shareholding ratio of the first shareholder).

In addition to the above control variables, the indicators of the intangible assets of enterprises, the number of authorized inventions (firpatent), and the growth rate of operating income (GROW) are taken as control variables on the basis of reading a large amount of literature in this paper.

\subsubsection{Construction of Model}

Based on the previous hypotheses, theoretical models are built in this section. In order to verify hypothesis 1 and hypothesis 2 , the following regression model is built.

$$
\begin{aligned}
& \operatorname{RD}_{i, t}=\beta_{\mathrm{O}}+\beta_{1} I T B_{i, t}+\beta_{2} F S_{i, t}+\beta_{3} \operatorname{ROE}_{i, t-1}+\beta_{4} S M_{i, t-1}+\beta_{5} A L R_{i, t-1} \\
& +\beta_{6} S I Z E_{i, t-1}+\beta_{7} G R O W_{i, t-1}+\beta_{8} Y E A R_{i, t-1}
\end{aligned}
$$

In order to verify hypothesis 3 , we innovatively introduce the interactive term ITB $\times$ FS of preferential tax policies and government subsidy policies in the empirical model to verify the interaction of the two policy instruments and establish the following regression model:

$$
\begin{aligned}
& R D_{i, t}=\beta_{0}+\beta_{1} I T B_{i, t}+\beta_{2} F S_{i, t}+\beta_{3}(T I B \times F S)_{i, t}+\beta_{4} R O E_{i, t-1}+\beta_{5} S M_{i, t-1} \\
& +\beta_{6} A L R_{i, t-1}+\beta_{7} S_{Z I Z E_{i, t-1}}+\beta_{8} G R O W_{i, t-1}+\beta_{9} Y_{E A R_{i, t}}
\end{aligned}
$$

\subsection{Descriptive Statistics and Correlation Test}

\subsubsection{Descriptive Statistical Analysis}

Key indicators involved in this paper are descriptively analyzed in this section, with the purpose of grasping the basic situation of fiscal and tax incentives and enterprise technological innovation through simple statistical analysis. The collected and processed data is descriptively analyzed in this section, and Table 1 shows the results of the analysis. Through the digging of descriptive statistical analysis results, the following conclusions are mainly summarized in this section. From the perspective of the R\&D investment of enterprises, the average value of $R \& D$ investment of enterprises is 0.0609 , which is lower than the median value. This shows that most companies' R\&D investment accounts for a small proportion of operating income. It can be seen that the companies' R\&D investment needs to be further strengthened. From the perspective of income tax benefit, the average value of corporate income tax benefit is 0.0286 , which is lower than the median value. This shows that the expenditure on corporate income tax has been greatly reduced under the guidance of the state. From the perspective of the intensity of fiscal subsidies, fiscal subsidies are more stable in the investment of technological innovation of enterprises. In general, the relevant indicators are more reasonable in distribution, and the empirical research and digging of sample data are scientific. 
Table 1. Descriptive statistical analysis results

\begin{tabular}{lccccccc}
\hline Variable & Obs & Min & Q1 & Q3 & Mean & Max & Sd \\
\hline RD & 1944 & 0.0000 & 0.0348 & 0.0706 & 0.0609 & 0.4650 & 0.0504 \\
ITB & 1944 & 0.0001 & 0.0163 & 0.0365 & 0.0286 & 0.1616 & 0.0186 \\
FS & 1944 & 0.0000 & 0.0040 & 0.0247 & 0.0195 & 0.2043 & 0.0245 \\
ROE & 1944 & 0.0000 & 0.0660 & 0.1665 & 0.1409 & 0.9206 & 0.1171 \\
SM & 1944 & 0.0035 & 0.1559 & 0.4682 & 0.4842 & 15.3506 & 0.9512 \\
ALR & 1944 & 0.0110 & 0.1341 & 0.3838 & 0.2703 & 0.7695 & 0.1659 \\
SIZE & 1944 & 0.0000 & 0.0000 & 0.0000 & 0.0000 & 0.0000 & 0.0000 \\
GROW & 1944 & -0.9106 & 0.0000 & 0.3590 & 0.3482 & 82.6992 & 2.3880 \\
\hline
\end{tabular}

3.2.2 Correlation Test

When using the multiple linear regression model to explore the impact of fiscal and tax incentives on technological innovation, we must first ensure that various impact factors of the hypotheses will not be affected by endogeneity. From this perspective, it is necessary to examine the mutual independence of the influencing factors of technological innovation in enterprises before conducting research. The STATA14.0 statistical tool are used for analysis in this section, and the empirical results are shown in Table 2. There is a correlation relationship between the income tax benefit, the intensity of fiscal subsidies, the investment in technological innovation of enterprises, and the synergistic effect between income tax benefit and the intensity of fiscal subsidies, and they are all significant under the condition of $1 \%$. This shows that through the correlation analysis between the various indicators in this study, the impact of fiscal and tax incentives on enterprise technology innovation is effectively confirmed in this section.

Table 2. Descriptive statistical analysis results

\begin{tabular}{|c|c|c|c|c|c|c|c|c|c|}
\hline & RD & ITB & FS & ROE & SM & ALR & SIZE & GROW & ITBFS \\
\hline RD & 1.000 & & & & & & & & \\
\hline ITB & 0.034 & 1.000 & & & & & & & \\
\hline FS & $0.447^{* \pi * \pi}$ & $0.270^{* \pi *}$ & 1.000 & & & & & & \\
\hline ROE & $-0.066^{* * \pi}$ & $0.316^{\text {ta }}$ & 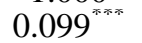 & 1.000 & & & & & \\
\hline SM & $0.194^{* \pi * \pi}$ & $0.494^{* \pi *}$ & $0.176^{* * *}$ & $0.230^{* \pi * \pi}$ & 1.000 & & & & \\
\hline ALR & $-0.265^{N * \pi}$ & $-0.276^{\pi * \pi *}$ & $-0.253^{* \pi * \pi}$ & $0.239^{\text {*a* }}$ & $-0.222^{\pi * \pi}$ & 1.000 & & & \\
\hline SIZE & $-0.055^{* * *}$ & $-0.038^{*}$ & -0.03 & -0.015 & $-0.041^{*}$ & $0.089^{* \pi * \pi}$ & 1.000 & & \\
\hline GROW & -0.025 & -0.011 & -0.01 & 0.019 & -0.018 & 0.027 & 0.027 & 1.000 & \\
\hline ITBFS & $0.255^{* \pi * \pi}$ & $0.599^{* \pi *}$ & $0.820^{\text {*A* }}$ & $0.200^{* * \pi *}$ & $0.308^{* * \pi}$ & $-0.248^{* \pi * \pi}$ & -0.033 & -0.013 & 1.000 \\
\hline
\end{tabular}

Note. Robust P-value in parentheses; ***p $<0.01, * * \mathrm{p}<0.05, * \mathrm{p}<0.1$

\subsection{Empirical Analysis}

The impact of fiscal and tax incentives on technological innovation of enterprises is explored in this section, mainly including two aspects: the difference in incentive effects between tax preference and fiscal subsidies; the impact of tax preference and fiscal subsidies on technological innovation of enterprises. The STATA14.0 statistical tool is used in this paper for analysis, and the empirical results are shown in Table 3.

Table 3. Empirical analysis of the impact of fiscal and tax incentives on enterprise technological innovation

\begin{tabular}{cccc}
\hline Variable & Predicted sign & Model $(1)$ & Model (2) \\
\hline FSit & + & $0.9533^{* * * *}$ & $\left(1.5789^{* * * *}\right.$ \\
& & $(22.25)$ & -0.0609 \\
ITBit & - & $-0.5462^{* * *}$ & $(-0.73)$ \\
& & $(-8.39)$ & 0.0058 \\
ROEit-1 & + & 0.0085317 & $(0.53)^{* * *}$ \\
& & $(0.77)$ & $0.0089^{* * *}$ \\
SMit-1 & + & $0.0093^{* * *}$ & $(7.58)^{* * *}$ \\
& & $(7.78)$ & $-0.0500^{* * *}$ \\
ALRit-1 & - & $-0.0566^{* * *}$ & $(-7.38)$ \\
& & $(-8.23)$ & $-5.58 \mathrm{E}-13$ \\
SIZEit-1 & - & $-5.52 \mathrm{E}-13$ & $(-1.22)$ \\
& & $(-1.18)$ & -0.0003 \\
GROWit-1 & - & -0.0003 & $(-0.68)^{* * *}$ \\
& & $(-0.65)$ & $-16.9286^{* * *}$ \\
(ITB $\times$ FS)it & - & & $(-9.11)$ \\
F-Statistics & & $57.50^{* * *}$ & $61.48^{* * * *}$ \\
Adj.R^2 & & 0.2893 & 0.3183 \\
N & & 1944 & 1944 \\
\hline
\end{tabular}




\subsubsection{Difference in Incentive Effects between Tax Preference and Fiscal Subsidies}

There are big differences in the incentive effects of tax preference and fiscal subsidies on the technological innovation of enterprises. According to the empirical results of model (1) in Table 3, the tax preference has a negative incentive effect on the technology innovation in enterprises, and fiscal subsidies have positive incentive effect on the technology innovation in enterprises. Tax preference has a negative impact on the technology innovation in enterprises, and are significant at the $1 \%$ level. This means that for every increase of income tax benefit, the technology innovation in enterprises will be reduced by 0.5462 units. The negative effect of income tax benefit on the technological innovation in enterprises is largely due to the unclear orientation of tax preference. As long as taxpayers are qualified for high-tech industries, they will want to receive tax preference even for the non-technical innovation activities, which leads to the weakening of technological innovation capabilities of enterprises under tax preference. Fiscal subsidies have a positive impact on the technological innovation in enterprises and are significant at the $1 \%$ level. This means that for every increased unit of fiscal subsidies, the technological innovation in enterprises will increase by 0.9533 units. Fiscal subsidies are special, in other words, fiscal subsidies can specifically subsidize technological innovation activities of enterprises. The fiscal subsidy policies have a clear policy orientation and can effectively stimulate the technological innovation in enterprises.

\subsubsection{Analysis of the Synergistic Effect of Tax Preference and Fiscal Subsidies}

The combination of tax preference and fiscal subsidies can produce synergistic effect. According to the empirical results shown in model (2), the intensity of fiscal subsidies significantly impacts the technological innovation in enterprises. Each additional unit of fiscal subsidy intensity means that the technological innovation in enterprises will increase by 1.5789 units. The impact of income tax preference on the technological innovation in enterprises in this model is not significant. From the perspective of the synergistic effect between tax preference and fiscal subsidies, it has a significant impact on the technological innovation in enterprises and is significant at the $1 \%$ level. From another point of view, the synergistic effect between tax preference and fiscal subsidies is negative, which means that for each additional unit of tax preference and fiscal subsidies, the corresponding technological innovation in enterprises is reduced by 16.9286 units. The fundamental goal of both tax preference and fiscal subsidies is to promote the technological innovation in enterprises. However, since the tax preference is aimed at innovative enterprises, not technological innovation activities, it leads to the expansion of the object of tax preference. In other words, in the actual practice of tax preference, the innovative companies enjoy tax benefits even without innovation activities, which causes the negative effect of tax preference on the technological innovation in enterprises. From another perspective, fiscal subsidies are special for the technological innovation in enterprises. Therefore, fiscal subsidies can directly stimulate the innovation activities. However, due to the expansion of the sample size, the innovative activities with fiscal subsidies are far less than that in the enterprises that are popularized by tax preference. Therefore, the synergistic effect between the two is significantly negative. In general, there is a synergistic effect between tax preference and fiscal subsidies. and it has a negative effect on the technological innovation in enterprises.

\section{Research Conclusions and Recommendations}

\subsection{Research Conclusions}

This paper draws the following conclusions through a combination of normative analysis and empirical analysis.

Firstly, there is a difference in the incentive effects of the two kinds of incentives, tax preference and fiscal subsidies, on the technological innovation in enterprises. Tax preference negatively affect the technological innovation in enterprises and is significant at the $1 \%$ level, which means that the technological innovation in enterprises will reduce by 0.5462 units for every increased unit of income tax preference. Fiscal subsidies positively impact the technological innovation in enterprises and are significant at the $1 \%$ level, which means that the technological innovation in enterprises will increase by 0.9533 units for every increased unit of fiscal subsidies. The reason why the tax preference and fiscal subsidies are different in the incentive effect of technological innovation in enterprises is reflected in that whether the policy orientation is clear.

Secondly, the combination of tax preference and fiscal subsidies can lead to synergistic effect. The synergistic effect between tax preference and fiscal subsidies is negative, which means that the corresponding technological innovation in enterprises will reduce by 16.9286 units for each increased unit of tax preference and fiscal subsidies. In the actual practice of tax preference, innovative enterprises enjoy tax benefits even without innovative activities, which causes the negative effects of technological innovation stimulated by the tax benefits. From another perspective, fiscal subsidies are special for the technological innovation in enterprises. There is synergistic effect between tax preference and fiscal subsidies, which has a negative effect on the technological innovation in enterprises. 
Finally, the incentive of tax preference and the technological innovation in enterprises are complementary. That is to say, the fiscal and tax incentive policies will promote the development of technological innovation in enterprises. and the benefits brought by the technological innovation in enterprises will prompt the state to introduce more powerful fiscal and tax policies. From this perspective, the incentive of fiscal and tax policies will reduce the costs of technological innovation in enterprises. The two manifestations of fiscal and tax policies are different in the incentive effects of technological innovation in enterprises, they all have a close relationship with the corporate innovation.

\subsection{Policy Suggestion}

According to the basic conclusions of empirical research, the corresponding suggestions are proposed from the national macro policy in this section.

Firstly, the government needs to appropriately increase the amount of fiscal subsidies. According to the empirical research conclusions, the fiscal subsidies can effectively promote the technological innovation in enterprises due to the special nature. While there are still quality deficiencies in the government fiscal subsidies for the technological innovation in enterprises. On the one hand, the government shall raise the "quality" of fiscal subsidies to stimulate the technological innovation in enterprises. The government sets up special subsidy funds for the technology innovation activities in enterprises. and makes reasonable subsidies according to the situation of technological innovation in enterprises. Only in this way can we ensure that the direction of fiscal subsidies is truly used for the technological innovation in enterprises. On the other hand, the government should increase the "quantity" of fiscal subsidies to stimulate the technological innovation in enterprises. The government also needs to expand the overall amount of fiscal subsidies to support more technology-based companies to achieve technological innovation. All in all, the government needs to improve the fiscal subsidy policies, and actively increase the number of technological innovations enjoying the fiscal subsidies.

Secondly, the government needs to improve preferential tax policies, making the preferential tax policies directional. In the previous study, it was pointed out that the object of preferential tax policies is technological enterprises rather than technological innovation activities. From this point of view, non-technology innovation activities of enterprises with high and new technology legal person qualification will also enjoy tax preference. Under these conditions, the preferential tax policies will lose the incentive effect on the technological innovation in enterprises. In view of this, the government needs to further narrow the object of preferential tax policies, that is the technological innovation activities with high-tech corporate legal person qualification. From this point of view, the specialization of the government preferential tax policies can effectively promote the technological innovation in enterprises. To sum up, the preferential tax policies can only promote the technological innovation in enterprises if they are used reasonably, stipulate the object of preferential tax policies, and clarify that which behaviors can enjoy tax benefits.

Finally, the Chinese government needs to set up the supervisory organizations for fiscal and tax incentive policies for the technological innovation in enterprises. The goal of the existence of supervisory organizations is to ensure that fiscal policies can be directly applied to the technology innovation activities in enterprises. According to the practice of fiscal and tax incentive policies at this stage, the fiscal and tax policies are often used by enterprises for non-technical innovation activities, causing that the incentive effect of fiscal and tax policies on the technological innovation in enterprises is not obvious. In view of this, the Chinese government needs to design special organizations to effectively supervise the fiscal and tax policies driving the technological innovation in enterprises. Through supervision, it aims to ensure the effectiveness of the effect of fiscal and tax policies to drive the technological innovation in enterprises.

\section{References}

Ajay, A., \& Richard, S. (2014). Affordability of cancer care in the United Kingdom - Is it time to introduce user charges? Journal of Cancer Policy, 2(2).

Camila, G., \& Annela, A. K. (2018). Could fiscal policies induce green innovation in developing countries? The case of Brazilian manufacturing sectors. Climate Policy, 18(2).

Cao, X. F. (2014). Government Subsidies and Enterprise R\&D Investment - An Empirical Study Based on Propensity Score Matching Method. Inquiry into Economic Issues, 9, 160-166.

Chen, Y. (2016). Government Support, High-Ttech and Enterprise Performance - Evidence of High-Tech Listed Companies. Finance and Accounting Monthly, 15, 57-62.

Clausen, T. H. (2009). "Do subsidies have positive impacts on R\&D and innovationactivities at the firm level?". Structural Change \& Economic Dynamics, 20(4), 239-253. https://doi.org/10.1016/j.strueco.2009.09.004 
Czarnitzki, D., Hanel, P., \& Rosa, J. M. (2011). Evaluating the Impact of R\&D Tax Credits on Innovation: A Microeconometric Study on Canadian Firms. Research Policy, 40(2), 217-229. https://doi.org/10.1016/j.respol.2010.09.017

Dai, C., \& Liu, Y. (2008). A Comparative Analysis of the Impact of Tax Preferences and Fiscal Subsidies on Enterprise R\&D. Economic Sciences, 03, 58-71.

Dominique, G., \& Bruno, P. (2003). The impact of public R\&D expenditure on business R\&D. Economics of Innovation and New Technology, 12, 225-243. https://doi.org/10.1080/10438590290004555

Gao, H. W. (2011). Research on the Extrusion Effect of Government Subsidies on the R\&D of Large State-Owned Enterprises. Forum on Science and Technology in China, 8, 15-20.

Gao, K. D. (2018). An Empirical Study of Tax Preferences, R\&D Investment and Enterprise Innovation. China Market, 8, 95-98.

Guo, J. X., \& Yuan, Z. M. (2018). Life Cycle, Fiscal Policies and Innovation Capability-Based on the Empirical Evidence of SMEs. Contemporary Finance and Economics, 3, 23-34.

Huang, H. B. Luo, J., \& Chang, J. (2017). Analysis on the Incentive Mechanism for High-Tech Enterprises to Develop Fiscal and Tax Policies. Science and Technology Management Research, 37(16), 68-72.

Li, H. Y., \& Cui, J. H. (2014). The Driving Effect of Coordination Mode of Tax Preferences and Direct Subsidies on Innovation. Taxation Research, 3, 85-89.

Li, L. M., \& Guo, C. Z. (2014). Is the Huge Tax Reduction and Exemption Effective in Promoting the Development of China's High-Tech Industry. Finance \& Trade Economics, 5, 14-26.

Li, Z. Y., \& Qi, X. D. (2017). Research on the Relationship between Government Fiscal Policies, Enterprise R\&D Input and Patent Output - Based on Panel Data of New Energy Vehicle Listed Companies in China. Journal of Liaoning University (Philosophy and Social Sciences Edition), 45(04), 31-41.

Lv, J. Q., \& Yu, D. D. (2011). Government Research Innovation Grant and Enterprise R\&D Investment: Extrusion, Substitution or Incentive? Forum on Science and Technology in China, 8, 21-28.

Ren, S. W., \& Ju, X. F. (2016). Research on the Relationship between Public Policies and SMEs' Technological Innovation Level Based on ESN Model. Journal of Northeast Agricultural University (Social Science Edition), 14(01), 7-16+23.

Shahrouz, A., \& Almas, H. (2014). The main support mechanisms to finance renewable energy development. Renewable and Sustainable Energy Reviews, 40.

Wu, J. M. (2016). An Empirical Analysis of the Three Stages of Preferential Tax Policies Affecting the Value of Technological Innovation - Taking the Data of Guangdong Maoming from 2001 to 2013 as An Example. Money China, (01), 272-275+277

Xin, Q., Zheng, Y., Gong, X., \& Sun, L. H. (2018). A Comparative Study on the Impact of Tax Preferences and Fiscal Subsidies on R\&D Investment of Chinese Traditional Medicine Enterprises. Chinese Traditional and Herbal Drugs,49(09), 2215-2220.

Xu, J. T., Zhang, B., Yan, S. Y. (2013). Research on Preferential Tax Policies for Enhancing Enterprise Technological Innovation Capability - Based on Macro Analysis of Jiangsu Province. Productivity Research, (01): 41-43+4.

Yang, X. D. (2018). Environmental Uncertainty, Tax Preferences and Technology Innovation - An Empirical Analysis Based on the Listed SMEs in China.Taxation Research, 3, 86-91.

Yu, M. G., Hui, Y. F., \& Pan, H. B. (2010). Political Connection, Rent Seeking and the Effectiveness of Local Government Fiscal Subsidy. Economic Research, 3, 22-26.

Yuan, J. G., Fan, W. L., \& Cheng, C. (2016). Tax Preferences and Enterprise Technology Innovation - An Empirical Study Based on Chinese Listed Companies. Taxation Research, 10, 28-33.

Zhang, F., \& Zhang, Y. D. (2018). The Impact of Fiscal Subsidies and Preferential Tax Policies on Business Performance in Competitive Fields. Finance and Trade Research, 29(03), 80-89.

Zheng, C. M., \& Li, P. (2015). The Impact of Government Subsidies and Tax Preferences on Enterprise Innovation Performance - An Empirical Study Based on GEM High-Tech Enterprises. Science \& Technology Progress and Policy, 16, 83-87. 
Zhou, G. R., Long, H. F., \& Li, X. H. (2018). An Empirical Study on the Contribution Rate of Technological Innovation to Industrial Economic Growth - Taking Tianjin as an Example. Industrial Innovation Research, 6, 14-19.

Zou, X. D. (2016). Tax Preferences, R\&D Investment and Enterprise Independent Innovation - An Empirical Analysis Based on A-share Listed Companies in Shanghai and Shenzhen Stock Exchanges. Journal of Liaodong University (Social Science Edition), 18(5), 64-70.

\section{Copyrights}

Copyright for this article is retained by the author(s), with first publication rights granted to the journal.

This is an open-access article distributed under the terms and conditions of the Creative Commons Attribution license (http://creativecommons.org/licenses/by/4.0/). 